\title{
Causing controversy: interpreting the requirements of causation in criminal law and tort law
}

\author{
GEMMA TURTON
}

University of Sydney Law School

AND

SALLY KYD

Leicester Law School*

\begin{abstract}
The occurrence of a fatal road traffic collision may raise a number of legal issues and result in litigation both in the civil and criminal courts. The role of the different branches of law is distinct, with the aims of the litigation being quite different, but both require causation to be proved. Such cases are examined in this article as a vebicle for discussing how the principles of causation play out in each branch of law. It will be seen that the particular aims of the law dictate how doctrines of causation are applied, with particular problems caused by the legislature's creation of strict liability offences. To resolve these problems, we propose that the criminal law borrow from negligence in adopting a test akin to the 'harm within the risk' test, adapting it to the role of the criminal law by formulating a 'barm within the wrong' requirement for causation.
\end{abstract}

Keywords: causation; tort; negligence; criminal law; harm; wrong; driving; responsibility

\section{Introduction}

$\mathrm{O}$ ne of the most common events in modern life likely to lead to involvement by a member of the public with both the criminal and civil justice systems of England and Wales is a road traffic collision (RTC). In 2018 there were 160,378 people killed or injured on Britain's roads as the result of a collision. ${ }^{1}$ The injured party, or bereaved relative, might seek compensation for their injuries or loss through the civil courts under the tort of negligence, while concurrently any negligent driver might be charged with an applicable criminal offence and prosecuted in either the magistrates' court or the Crown Court. The two branches of law will be engaged for two different purposes, to be explored throughout

* Gemma Turton is Senior Lecturer at the University of Sydney Law School; Sally Kyd is Professor of Law at Leicester Law School. We would like to thank the reviewers for their constructive comments on earlier drafts, as well as a number of other individuals who commented on previous drafts, including Findlay Stark, Matt Dyson, Sandy Steel and Sarah Green. An early version of this paper was presented at the Society of Legal Scholars 2014 annual conference, and we wish to thank Leicester Law School for financial and study leave support in the development of this article.

1 Department for Transport, Reported Road Casualties in Great Britain: Main Results 2018 (Department for Transport 2019) <www.gov.uk/government/statistics/reported-road-casualties-great-britain-main-results$2018>$. 
this article, but at the same time they are, as recently noted by Dyson, 'tightly bound together'. ${ }^{2}$

Let us take a not atypical scenario involving a fatal RTC to frame the question we seek to address. According to Clarke et al, right of way violations are the cause of a significant proportion of collisions. ${ }^{3}$ Such collisions typically involve a number of factors converging at once to produce tragic consequences. These factors might include a failure to abide by the rules of the road by more than one road user: typically a car driver who fails to look properly in order to ensure that the road across which they intend to turn is clear of other traffic, and a motorcyclist travelling towards the car in excess of the speed limit. ${ }^{4}$ In such a case, whether the Crown is able to secure a conviction for causing death by careless driving ${ }^{5}$ will depend upon two main factors: that D's driving fell below the standard of a competent and careful driver, thus amounting to careless driving, ${ }^{6}$ and that D's careless driving caused V's death. Whether the deceased's estate is able to sue for damages in negligence will depend on similar questions: did D breach a duty of care owed to $\mathrm{V}$ ? The standard of care applied to determine whether D breached such a duty is similar to that under the criminal law of driving without due care and attention (careless driving): the standard of the reasonably competent driver. ${ }^{7}$ Secondly, did the breach of duty cause the death? The different contributions to the collision can be represented in a reduction of damages due to contributory negligence. ${ }^{8}$ If $\mathrm{V}$ was speeding, this is likely to provide a reduction of around 50 per cent, ${ }^{9}$ although in the worst cases D's contribution might be reduced to as little as 20 per cent where the claimant's speed was particularly excessive. ${ }^{10}$ In a criminal prosecution for a causing death offence, however, the issue is one of 'all or nothing' liability. D is either liable for causing death, or they are not. ${ }^{11}$

What if V is 100 per cent to blame for the RTC? Careless driving on D's part could not be proved in such a case, but what of an offence of causing death by unlawful driving under s 3ZB Road Traffic Act 1988, which provides that a person is guilty of an offence if he causes the death of another person by driving a motor vehicle on a road when he is unlicensed or uninsured? ${ }^{12}$ The offence is one of strict liability, in that the defendant need not be aware that they were unlicensed, uninsured, or disqualified; neither need they have any mens rea in relation to causing death or even creating the risk of any harm. Much, then,

2 M Dyson, 'Disentangling and Organising Tort and Crime' in M Dyson (ed), Unravelling Tort and Crime (Cambridge University Press 2014) 20. For an alternative approach to comparing causation in the two branches see A P Simester, 'Causation in (Criminal) Law' (2017) 133 Law Quarterly Review 416.

3 In a sample of fatal RTCs examined to establish their cause, 16 per cent involved right of way violations, leading Clarke et al to identify this as one of two problematic areas for road safety, the other being loss of control collisions, making up 44 per cent of fatal RTCs: D Clarke, P Ward, C Bartle and W Truman, 'Killer Crashes: Fatal Road Traffic Accidents in the UK' (2010) 42 Accident Analysis and Prevention 764, 768.

4 Such examples can be seen in an empirical study of prosecutions brought as a result of fatal road traffic collisions: S Cunningham, 'Has Law Reform Policy Been Driven in the Right Direction? How the New Causing Death by Driving Offences are Operating in Practice' (2013) 9 Criminal Law Review 712.

5 This is the most likely charge to be brought, under s 2B Road Traffic Act 1988. See Cunningham (n 4).

6 Road Traffic Act 1988, s 3ZA.

7 Nettleship v Weston [1971] 2 QB 691 (CA).

8 Law Reform (Contributory Negligence) Act 1945, s 1(1).

9 See, for example, Wheeler v Chief Constable of Gloucestershire Constabulary and Others [2013] EWCA Civ 1791.

10 See, for example, Ringe v Eden Springs (UK) Ltd [2012] EWHC 14 (QB); Train v Secretary of State for Defence [2014] EWHC 1928 (QB).

11 Although it is recognised that the contribution of the victim's own negligence can be taken into account as a mitigating factor in sentencing.

12 Until 2015 it also included causing death by driving whilst disqualified, but a separate offence was created by s 29 of the Criminal Justice and Courts Act 2015, which inserted s 3ZC into the Road Traffic Act 1988. 
depends on the interpretation of the requirements of causation in such a case, an issue that was considered by the Court of Appeal in $\mathrm{R} v$ Williams $^{13}$ and $\mathrm{R} v$ Hughes, ${ }^{14}$ before being clarified by the Supreme Court. ${ }^{15}$ As will be seen, Hughes may have reduced the injustice created by the offence being one of strict liability by incorporating a fault requirement into causation, but it remains the case that a defendant may be convicted under s $3 \mathrm{ZB}$ in circumstances where she would not have been liable to compensate the victim in the tort of negligence. This paper considers the question of what it means 'to cause death by driving' from the perspectives of both criminal law and negligence. ${ }^{16}$

There are a number of aspects of criminal law that result in criminal liability where no civil liability is incurred, such as the meaning of appropriation in the law of theft, ${ }^{17}$ or the unavailability of defences such as consent or ex turpi causa which could lead D to avoid liability in tort. ${ }^{18}$ Indeed, attempts liability exists in criminal law - but not in negligence, where damage is required - since criminal law is concerned with censuring wrongs, including the wrong in second-order harms such as threats to security even, in relation to some inchoate crimes and endangerment offences, where specific 'victims' may be unidentifiable. As Lord Scott stated in Ashley v Chief Constable of Sussex Police, '[a] plea for consistency between the criminal law and the civil law lacks cogency for the ends to be served by the two systems are very different'. ${ }^{19}$ Dyson summarises these ends:

... criminal law responds to moral, natural or public wrongs with a penalty and should be characterised by clear, certain and formal rules; tort law responds to many of the same moral and natural wrongs, but does so for private parties and tends to focus on putting the wrong right, rather than punishing. ${ }^{20}$

This paper is concerned with causation and the question of how the purposes of the two systems of law are reflected in their respective causal doctrines. Causation is intimately tied up with notions of responsibility, indeed in Environment Agency v Empress Car, Lord Hoffmann stated that 'one cannot give a common sense answer to a question of causation for the purpose of attributing responsibility under some rule without knowing the purpose and scope of the rule'. ${ }^{21}$ Our focus, then, is on the place of causation in these different systems of responsibility. The offence and facts in Hughes raise thorny questions about causation in the context of strict liability and where the victim was also at fault. We address these in section three of the paper where we identify the need for a more nuanced approach to legal causation where liability is strict, and in the final section we advocate developing a 'harm within the wrong' test to keep criminal liability within appropriate bounds. First though, it is helpful to articulate some of the more basic divergences in approach to causation and to situate them within the purposes of the two fields of law. In part this is because, while these divergences are commonly known, they

$13 \mathrm{R} v$ Williams [2010] EWCA Crim 2552, [2011] 1 WLR 588.

$14 \mathrm{R} v$ Hughes [2011] EWCA Crim 1508, [2011] 4 All ER 761.

15 R $v$ Hughes [2013] UKSC 56, [2013] 1 WLR 2461.

16 Unless otherwise stated, any reference to 'negligence' refers to the tort of negligence under civil law.

17 R $v$ Hinks [2001] 2 AC 241. For a comparison of the crime of theft and the civil wrong of conversion, see S Green, 'Theft and Conversion - Tangibly Different?' (2012) 128 Law Quarterly Review 564. For other comparisons between the civil and criminal law, see Dyson (ed), Unravelling Tort and Crime (n 2).

18 G R Sullivan, 'Wrongs and Responsibility for Wrongs in Crime and Tort' in M Dyson, Unravelling Tort and Crime (ed) (n 2) 85.

19 Ashley v Chief Constable of Sussex Police [2008] UKHL 25, [2008] AC 962, [17].

20 M Dyson, 'Tortious Apples and Criminal Oranges' in M Dyson (ed), Comparing Tort and Crime: Learning from Across and Within Legal Systems (Cambridge University Press 2015) 421.

21 Environment Agency v Empress Car Co (Abertillery) Ltd [1999] 2 AC 22 (HL), 31. 
are rarely articulated side by side, and in part it helps contextualise the analysis of the specific problems of strict liability that later arise.

\section{Divergences in approach to causation in criminal law and negligence law}

Depending on one's perspective, the law on causation in negligence is more fully developed than in criminal law, or as Sullivan describes it 'causation in the criminal law is a less cluttered field than is the case in tort law'. ${ }^{22}$ The purpose of this section is to identify the differences in basic approach to causation in the two fields and to posit some possible explanations. Our focus is on the approaches to factual causation and novus actus interveniens, but for clarity's sake we begin by outlining the general approach to causation in each area of law. A complete account of causation in each field is beyond the scope of this work, but a broad outline helps locate key points of divergence.

A thread common to both branches of law is the distinction drawn between issues of factual and legal causation. Glanville Williams explains the nature of these inquiries:

When one has settled the question of but-for causation, the further test to be applied to the but-for cause in order to qualify it for legal recognition is not a test of causation but a moral reaction. The question is whether the result can fairly be said to be imputable to the defendant... If the term cause must be used, it can best be distinguished in this meaning as the 'imputable' or 'responsible' or 'blameable' cause, to indicate the value-judgment involved. ${ }^{23}$

We will return to this concept of moral responsibility later; for now, it suffices to note that the distinction between factual causation and legal causation, in both branches of law, broadly corresponds to the division between factual issues and evaluative questions about responsibility. Factual causation is established in negligence using the but-for test, ${ }^{24}$ or the Wardlaw test of material contribution to harm, ${ }^{25}$ and legal causation comprises the Wagon Mound test of reasonable foreseeability of the type of harm as the test of remoteness, 26 subject to the thin skull principle that the extent of harm need not be foreseeable, ${ }^{27}$ and the novus actus interveniens doctrine. In criminal law, factual causation is a narrower test determined using the but-for test alone; ${ }^{28}$ then at the legal causation stage courts ask whether there was a novus actus interveniens, meaning that this but-for cause was no longer substantial and operating ${ }^{29}$ at the time of the relevant harm. ${ }^{30}$

Causation in negligence is more developed in two key senses. First, the tests of factual causation (and development of exceptional tests) have been the subject of a number of judicial decisions and academic discussion in recent years. ${ }^{31}$ Second, as Sullivan highlights,

22 Sullivan (n 18) 102.

23 G Williams, Textbook of Criminal Law (2nd edn, Sweet \& Maxwell 1983) 381. For the need of the legal system to make this distinction in relation to a road traffic fatality specifically, see A Merry and A McCall Smith, Errors, Medicine and the Law (Cambridge University Press 2001) 132.

24 Barnett v Chelsea and Kensington Hospital Management Committee [1968] 2 WLR 422 (QB).

25 Exceptionally the Fairchild test of material contribution to the risk of harm may apply, but this test is confined to very limited cases: Fairchild v Glenhaven Funeral Services Ltd [2002] UKHL 22.

26 The Wagon Mound (No 1) [1961] AC 388.

27 Smith v Leech Brain \& Co Ltd [1962] 2 QB 405.

28 The usual authority cited for this rule is White [1910] 2 KB 124.

29 D Ormerod and K Laird, Smith and Hogan's Criminal Law (14th edn, Oxford University Press 2015) 95. A number of cases can be cited as authority for this test, including $R v$ Smith [1959] 2 QB 35.

30 See discussion below.

31 Key examples are the Fairchild exception: Fairchild (n 25); developments of the Wardlaw test such as Bailey $v$ MOD [2008] EWCA Civ 883 and Williams v Bermuda Hospitals Board [2016] UKPC 4; and Chester v Afshar [2004] UKHL 41. 
[b]roadly, under criminal law, questions of whether an outcome was foreseeable and not too remote ... are not entertained at the stage of causation/actus reus. ${ }^{32}$ The evaluative work is done instead by mens rea, a point which acquires greater significance when we later consider strict liability offences where, of course, there is not a mens rea requirement. We now consider possible explanations for these divergences.

\subsection{FACTUAL CAUSATION}

In relation to factual causation one might expect the law in both areas to align; since evaluative issues are primarily the realm of legal causation, the different objectives of liability in the two fields would naturally acquire greater significance there. In negligence, courts have faced increasingly complex factual issues, particularly in the industrial disease and medical contexts. These are arguably inescapable given the central role causation plays in connecting the claimant to the defendant in a system of interpersonal responsibility and have led to the factual/legal causation divide becoming more pronounced. It might also be suggested that negligence law has developed more detailed and tightly focused tests for the more practical reason, identified by Hart and Honoré, that causation serves wider functions in negligence than in criminal law. In criminal law generally 'a causal connection between some action of the accused and the specified harm must be shown in order to establish the existence of liability', while 'in tort causal questions are usually relevant both to the existence of liability and to its extent'. ${ }^{33}$ Since the extent of the harm caused by the negligence determines the quantum of damages for which $\mathrm{D}$ is liable, it is natural that negligence law more finely delineates the relationship of causation.

This impacts on the approach to causation where the defendant's act or omission merely accelerates an outcome. In $\mathrm{R} v$ Morby, the father failed to seek medical treatment for his son who died of smallpox, and his conviction was quashed because it was not proven that the omission 'caused death or accelerated it'. ${ }^{34}$ In Simester's view, acceleration of the outcome would not be a sufficient basis to conclude that the father caused the child's death if treatment would ultimately have failed. ${ }^{35}$ In similar circumstances, however, negligence liability may be imposed (where a duty of care is owed) but, as noted earlier, causal considerations affect not only the existence of liability but also its extent; the claimant's already shortened life-expectancy can be taken into account at the quantification stage. ${ }^{36}$ Following Williams v Bermuda Hospitals, ${ }^{37}$ a negligent delay in treatment may materially contribute to the outcome and therefore be a cause when it permits the claimant's condition to worsen, even if on the balance of probabilities the ultimate outcome is unchanged. This was not an uncontroversial decision, ${ }^{38}$ but on orthodox principles, if the delay in treatment itself causes damage in the form of worsening the condition or causing a longer period of pain and suffering prior to diagnosis then the defendant may be held liable for that if not the final outcome. ${ }^{39}$ The flexibility that exists in negligence to conclude that the defendant's omission caused part of the total loss or accelerated its occurrence allows for a wider range of contributions

32 Sullivan, (n 18) 102.

33 H L A Hart and Tony Honoré, Causation in the Law (2nd edn, Oxford University Press 1985) 8485.

$34 \mathrm{R} v$ Morby (1882) 8 QBD 571, 575 (Stephens J) cited in Simester (n 2) 437.

35 Simester (n 2) 437.

36 See e.g. Smith v Leech Brain \& Co Ltd [1962] 2 QB 405.

37 Williams v Bermuda Hospitals Board [2016] UKPC 4.

38 See e.g. S Green, 'Q: When is a Material Contribution not a Material Contribution? A: When It Has not Been Proven to have Made any Difference to the Claimant's Damage' (2016) 32 Professional Negligence 169.

39 Hotson v East Berkshire HA [1987] AC 750 (HL). 
to be treated as causal than may be the case in criminal law. On the other hand, the 'all or nothing' nature of liability in criminal law makes the meaning of causation of great importance, so one could equally expect the criminal law to have developed clear and consistent principles as to its application.

A further possible reason for the divergence is identified by Shute: he argues that the reason why the (criminal) law tends to regard causation in terms of broad generalisations based on common sense principles rather than to mimic the more obscure approach to causation often taken by the philosopher or scientist (or perhaps the tort lawyer) is that in criminal law jurors need to understand causal principles. ${ }^{40}$ This is, of course, true of cases triable on indictment, and, for offences triable summarily or either way, the factfinders who must understand the law are often non-legally qualified lay magistrates, as opposed to the legally experienced judge making decisions as to causation in negligence cases. A related point is that the burden of proof is different in criminal cases compared to civil cases. In a criminal case, the fact-finders can only convict if they are 'sure' of the accused's guilt (including that D caused the relevant harm in the case of a result crime), whereas in a civil case the claimant's case only need be proved 'on the balance of probabilities'. Beyond these differences, we now turn to consider the causal issues that arise, and how they are addressed, when the victim was also at fault.

\subsection{CAUSATION AND THE VICTIM'S OWN CARELESSNESS}

The victim's own carelessness introduces causal complexities in both criminal law and negligence, and, while it goes to the existence of liability in both fields through the doctrine of novus actus interveniens, in negligence it may affect the extent of liability through the defence of contributory negligence. This, we suggest, reflects the different aims of punishment and allocation of responsibility and affects how issues of novus actus are resolved in each field.

To contextualise the discussion of the victim's own carelessness, where a novus actus is the act of a third party, in both negligence and criminal law it is worth noting that liability is not binary. If a subsequent act of a third party, such as a medical practitioner, does not break the causal chain, that third party does not necessarily escape liability. She may commit a criminal offence such as gross negligence manslaughter ${ }^{41}$ and, in negligence, may be held jointly and severally liable along with the defendant for the additional damage caused. Conversely, the simple fact that the third party commits a criminal offence or is negligent does not entail that she breaks the chain of causation in criminal law and negligence respectively. Indeed, given that negligent medical treatment is a foreseeable and not uncommon event, it will generally not break the chain of causation in either field. If anything, criminal law appears to take a stricter approach to subsequent medical negligence, requiring treatment to be so bad as to be so independent and so potent in causing death as to be a supervening act, ${ }^{42}$ while in negligence it seems that gross medical negligence would break the chain of causation resulting in $\mathrm{D}$ avoiding liability for the additional damage. ${ }^{43}$ On one hand, it seems strange that negligence law will more readily accept that medical treatment breaks the chain of causation than criminal law since, where joint and several liability applies, this recognises the responsibility of both defendants. However, criminal law censures not only the causation of harm but the

40 S Shute, 'Causation: Foreseeability v Natural Consequences' (1992) 55 Modern Law Review 584, 584.

41 Applying the test in Adomako [1995] 1 AC 171.

42 R v Cheshire (1991) 93 Cr App R 251.

43 Webb v Barclays Bank [2001] EWCA Civ 1141, [2002] PIQR P8. 
intention to cause it; given the moral luck that causation involves, ${ }^{44}$ it is understandable that it should be confined to a small role with more significance placed on the need to punish the blameworthy assailant in addition to the blameworthy medic.

The contrasting rationales behind negligence and criminal law become more significant where the potential novus actus is an act of the victim. While the criminal liability of the defendant remains all or nothing, in negligence the responsibility for the damage can be shared between the claimant and defendant through the defence of contributory negligence. The conclusion in a criminal trial is thus a rather stark one to be determined by the fact-finders: $\mathrm{D}$ is either 'guilty' or 'not guilty' of the offence charged. ${ }^{45}$ Where guilt is established, Simester argues that 'the scalarity of causation should directly affect sentencing, in as much as differences in one's degree of causal responsibility would imply differences in one's degree of culpability'. ${ }^{46}$ However, it is still true to say that criminal liability is 'all or nothing' in the sense that if the victim's conduct constitutes a novus actus, liability will not ensue. A novus actus of the claimant would similarly result in the defendant escaping liability in negligence, but the availability of the contributory negligence defence means that the role of the claimant can more readily be taken into account and lead to apportionment of damages where the claimant acted negligently, albeit not in a manner that amounted to a novus actus. Thus, in the decision in Scott v Gavigan, the Court of Appeal considered it preferable that the claimant's negligence in a road traffic collision should constitute contributory negligence rather than a novus actus in all but 'pretty exceptional circumstances'. ${ }^{47}$ Clarke LJ explained that because it is not uncommon for someone to run out into the road, this is a risk that drivers should foresee. Since they therefore '[owe] a duty to take care not to injure even the foolish, I find it difficult to see why [they] should be absolved of all liability and the claimant denied any relief save in extreme circumstances', ${ }^{48}$ The primary question for criminal law in such circumstances is whether D's act of driving is sufficiently blameworthy to attract liability for the end result. The difference is that V's own negligence could not influence the outcome of the case, unless it were in fact extreme enough to absolve $\mathrm{D}$ of liability. ${ }^{49}$ Steel argues that if . . . the rules on intervening agency are the legal precisifications of the broad question "Whose doing

44 Simester states that what he labels 'mechanical' causation is the 'primary vehicle for allocating moral luck': Simester (n 2) 423.

45 Although it is true that one should not overemphasise the role of the fact-finders in determining the conclusion, in the sense that the outcome of a criminal case depends upon a number of factors, not least the selection of offences to be charged by the Crown and the decision of $\mathrm{D}$ to plead guilty or not guilty to such charges or lesser included offences.

46 Simester (n 2) 424.

47 Scott $v$ Gavigan [2016] EWCA Civ 544 [34].

48 Ibid.

49 In Scott v Gavigan (ibid) the V suffered a 'significant injury' to his leg. In that situation, a criminal court would not be called upon to decide whether D had 'caused' the injury unless D's driving was considered dangerous, and so he might be liable for an offence under s 1A Road Traffic Act 1988, or if he were disqualified from driving, in which case he might be liable for the offence under s 3ZD Road Traffic Act 1988. Otherwise, D might be liable, not for the end result, but for an endangerment offence such as careless driving, if it was thought that his failure to avoid $\mathrm{V}$ amounted to driving which fell below the standard of a competent and careful driver, in which case V's injuries are irrelevant to the charge. Parliament's approach has been rather piecemeal in introducing constructive result crimes from underlying conduct crimes, and it is this which has created the headache for courts in determining issues of causation in such cases. Following its most recent consultation on driving offences, the government intends to bring forward proposals to create a new offence of causing serious injury by careless driving: Ministry of Justice, Response to the Consultation on Driving Offences and Penalties Relating to Causing Death or Serious Injury (Cm 9518, 2017) <www.gov.uk/government/uploads/system/uploads/attachment_data/file/651879/consultation-responseon-driving-offences.pdf $>$. 
was this?", then we would not expect the rules to vary between tort and crime'. 50 Tort law, however, is much more readily able to handle the answer that it was the doing of both the claimant and defendant since the aim is allocation of responsibility rather than blame or censure. This may explain, for example, why in Pagett police officers who shot towards D, killing the girlfriend he was using as a human shield, were seen to be acting involuntarily out of self-preservation and in the line of duty and did not break the chain of causation between D's act and V's death, despite being liable to V's mother in civil law. ${ }^{51}$

Additionally, negligence law tends not to ask such an open-ended question as 'Whose doing was this?'. Instead, the causation inquiry is tightly framed by prior conclusions about damage, duty and breach, so that we ask whether the defendant's failure to take reasonable care, in breach of a duty owed to the claimant, caused the damage that the claimant suffered. In criminal law, causation is constitutive of the actus reus of an offence so bears the burden of tasks that, in negligence, would be addressed by duty and breach. Many evaluative questions about responsibility and blame are traditionally addressed within mens rea. In the absence of a mens rea requirement, those evaluative questions remain to be addressed, but, we will argue, it is inappropriate to attempt to subsume them within the causation inquiry.

The case of Hughes raises the difficult question of the weight to be given to the victim's own carelessness when D's liability is strict, so is not premised on carelessness on D's part. The defendant in Hughes had been driving his camper van uninsured when he was confronted with the victim's oncoming car, which veered onto D's side of the carriageway and collided with the camper van. It was found that the deceased had been under the influence of drugs and overtired, and it was accepted that D's driving was faultless and that he could have done nothing to avoid the collision. ${ }^{52}$ The relevant offence in this case was s 3ZB Road Traffic Act 1998 according to which D is guilty of an offence if he causes the death of another person by driving a motor vehicle on a road and, at the time when he is driving, he is uninsured. Since the victim did not voluntarily and deliberately kill himself this was not a case of novus actus interveniens but of concurrent causes, and the question was whether the driving of D was a cause of V's death. The Supreme Court went on to hold that in order to find that D so caused the death of V there must be 'at least some act or omission in the control of the car, which involves some element of fault ... which contributes in some more than minimal way to the death', and on the facts this fault was missing. ${ }^{53}$ While it is understandable that the court would seek to introduce an element of fault into a homicide offence, it will be argued that the way in which this was done does not provide a coherent basis for criminal liability that can be of general application.

In determining liability, one issue that troubled the court was that $\mathrm{V}$ 'was not an innocent victim and could never have recovered any compensation if he had survived injured'. ${ }^{54}$ Although the facts of Hughes are typical of those that could potentially give rise

50 S Steel, 'Causation in Tort Law and Criminal Law: Unity or Divergence?' in M Dyson (ed), Unravelling Tort and Crime (n 2) 272.

51 R v Pagett (1983) 76 Cr App R 279. See A Norrie, Crime, Reason and History: A Critical Introduction to Criminal Law (3rd edn, Cambridge University Press 2014) 185. The High Court awarded $f^{\prime} 8000$ to V's mother several years later (3 December 1990); presumably what counts as 'reasonable' will vary between self-defence in criminal law and the standard of care in negligence.

52 Other than to not have been driving at the time and on the road to be involved in a collision.

$53 \mathrm{R} v$ Hughes [2013] UKSC 56, [36].

$54 \mathrm{R} v$ Taylor [2016] UKSC 5, [9]. The certified question also made specific reference to circumstances where the manner of the defendant's driving was faultless and 'the deceased was (in terms of civil law) 100\% responsible for causing the fatal accident or collision', at [35]. 
to negligence liability, we should not allow this to cloud our thinking by encouraging us to analyse the issues arising from the case in negligence terms. While it might be thought that of the two branches of law it is criminal law, not tort, which ought to be the more restrictive, the reason there is no negligence liability on the facts of Hughes is simply that the defendant had not breached a duty of care towards the victim. This outcome does not turn on causation because in the absence of a breach of duty there is no causation question to be asked. While causation is constitutive of actus reus in criminal law, in negligence liability the causation question is tightly framed by the damage and breach of duty, so causation questions simply do not arise in the absence of a breach, for example, failure to drive with reasonable care.

There is therefore a limit to how useful it was, given the current position, for the Supreme Court to highlight the different outcome in negligence when addressing the causal requirement in criminal law. If the court's concern was simply that there may be criminal liability in circumstances that would not attract negligence liability, then, as we have seen, there are sometimes good reasons for differences in the law. If the court's concern instead was that the $\mathrm{s} 3 \mathrm{ZB}$ offence is primarily concerned with the absence of insurance and the financial harm caused to claimants who are subsequently uncompensated, then it may be concerning that criminal liability can arise where there would be no tortious liability, but this is a concern which should be directed at the drafting of the legislation. A more coherent approach would have been for Parliament to add the absence of insurance as an aggravating factor to the causing death by careless driving offence, along the lines of the offence under s 3A of the Road Traffic Act 1988, which carries a maximum sentence of 14 years' imprisonment where death caused by careless driving is aggravated by $\mathrm{D}$ driving under the influence of alcohol or drugs. ${ }^{55}$ Moreover, the Supreme Court's solution does not avoid this risk, since criminal liability will now arise under s $3 \mathrm{ZB}$ where there is something properly to be criticised in the manner of D's driving, which still does not amount to careless driving so may also not amount to negligence.

What the offence under s $3 Z \mathrm{ZB}$ highlights in particular is the idea that it is the balance that needs to be struck between the role played by moral luck, on the one hand, and blameworthiness, on the other, that is perhaps key to determining the demands placed on causation in criminal law. Many of the leading cases on causation in criminal law are cases of constructive or 'unlawful act' manslaughter, ${ }^{56}$ where the harm actually caused might be far out of proportion to the blameworthiness of D. Lord Goff's recognition in Pagett that the fact that causation is present will not necessarily lead to a conviction for murder or manslaughter, since other elements of the offence such as mens rea must be proved, is tempered by his admission that 'in the majority of cases he is likely to be guilty at least of manslaughter'. ${ }^{57}$ Given the ease with which unlawful act manslaughter can be proved, in that $\mathrm{D}$ need have no awareness of the risk of death or harm she poses to her victim, unlawful act manslaughter has come under fire from subjectivist criminal law commentators who see the breach of the principle of correspondence (requiring that the mens rea of an offence relate to the proscribed harm resulting from the actus reus) and the

55 It is by no means suggested that a maximum of 14 years would be proportionate for such an aggravated offence, however. It can also be argued that such a separate offence would not be required, given that lack of insurance operates as an aggravating factor in sentencing: Sentencing Guidelines Council, Causing Death by Driving: Definitive Guideline (Sentencing Guidelines Council 2008) <www.sentencingcouncil.org.uk/wpcontent/uploads/Causing-death-by-driving-definitive-guideline-Web.pdf $>$.

56 For more in-depth discussion of this point, see S Kyd, 'Causing Death' in M Bohlander and A Reed (eds), Homicide in Criminal Law: A Research Companion (Routledge 2018).

$57 \quad \mathrm{R} v$ Pagett (n 51) 289. 
emphasis on the role of luck as problematic. ${ }^{58}$ Objectivists, on the other hand, see little problem with finding $\mathrm{D}$ liable for causing death where she has made her own moral luck. ${ }^{59}$ That does, however, result in an increase in the importance of the clarity of the law on causation, which is currently lacking. ${ }^{60}$

Moral luck encompasses luck as to a range of matters: the outcomes we cause, the circumstances we find ourselves in and our own disposition. Nagel advanced the view that moral judgements cannot be isolated from the effects of luck; moral judgements are sensitive to factors that we have no control over. ${ }^{61}$ The concept of causation is, clearly, important to identifying outcomes as 'ours', distinguishing those outcomes that we can be said to have caused despite the role of luck from those that we cannot be said to have caused. But, as Ashworth identifies, we need to separate from causal responsibility 'certain questions of moral responsibility: is she morally to blame for the accident? Does he have a moral duty to compensate the owner of the vase?' 62 In negligence, a degree of stigma will inevitably flow from a finding of liability, and this will vary depending on the damage caused, which does entail a role for outcome luck, yet the remedy remains compensation and the tort remains negligence. In contrast, Ashworth argues, 'the criminal law is chiefly concerned with desert, that is, with whether or not the person deserves to be labelled as a criminal and, if so, what level of offence is fairly applicable ... culpability is a crucial issue'. ${ }^{63}$ Where there is luck as to the outcome caused, this potentially affects not only the existence of liability in criminal law, but also the offence for which $\mathrm{D}$ is convicted, with the labelling function affecting the degree of stigma attached and the severity of the punishment imposed. A minor assault can become manslaughter if the victim dies, even where the risk of death was not foreseeable. Given that criminal law invites a wider range of moral judgements to be made against the defendant than negligence law, we might expect outcome luck to be confined to a smaller role through more restrictively applied causal concepts. Instead, it seems to be negligence law that allows a smaller role for outcome luck by requiring that the type of harm suffered would have been reasonably foreseeable.

Horder seeks to defend unlawful act manslaughter against concerns about the increased role it gives to moral luck, arguing that 'the existence of an intention to do wrong may make it legitimate to hold someone criminally responsible for any adverse consequences of which there was a risk in committing the intended wrong, whether it could be said that the risk would reasonably foreseeably turn into a reality or not'. ${ }^{64} \mathrm{He}$ distinguishes between two defendants who discharge guns close to the victim who suffers a shock and consequently dies of a heart attack. The defendant whose gun went off while he was unlawfully cleaning it has probably not committed manslaughter but, Horder argues, the defendant who deliberately fired his gun near to the unsuspecting victim is in a morally different position because he has made his own luck by directing his efforts

58 See, for example, A Ashworth, 'Change of Normative Position: Determining the Contours of Culpability in Criminal Law' (2008) 11 New Criminal Law Review 232; B Mitchell, 'More Thoughts about Unlawful and Dangerous Act Manslaughter and the One-punch Killer' [2009] Criminal Law Review 502.

59 See, for example, J Horder, 'A Critique of the Correspondence Principle in Criminal Law' [1995] Criminal Law Review 759.

60 See, for example, Carey [2006] EWCA Crim 17; commentary of Carey by D Ormerod: [2006] Criminal Law Review 842.

61 T Nagel, Mortal Questions (Cambridge University Press 2013) 24-38.

62 A Ashworth, 'Taking the Consequences' in S Shute, J Gardner and J Horder (eds), Action and Value in Criminal Law (Clarendon Press 2013) 112.

63 Ibid 117.

64 Horder (n 59) 764. 
towards harming the victim, so is morally responsible for the death.

Negligence liability clearly does not require intention to harm, but the conduct giving rise to negligence liability is 'directed' towards the claimant in as much as the defendant must have owed a duty of care to the claimant and must have exposed the claimant to an unreasonable risk of harm. The conduct underlying the offence in s $3 Z B$ is the strict liability offence of driving whilst uninsured. It is not 'directed' towards harming the victim. Since the defendant need have no knowledge that she is uninsured, she has not altered her moral position vis-à-vis the victim. It is the outcome, involving outcome luck, that is primarily being invoked to justify a moral judgement and criminal liability for the death. This increases the demands that are placed on causation, and in the final section we now consider how best to address these.

\section{Causation and strict liability: a 'harm within the wrong' test for strict liability result crimes}

The decision in Hughes has not been confined to the s $3 \mathrm{ZB}$ offence; in $\mathrm{R} v$ Taylor, the Supreme Court held that it extends to the offence under s $12 \mathrm{~A}(2)(\mathrm{b})$ of the Theft Act $1968^{65}$ under which a person is guilty of aggravated vehicle-taking if, owing to the driving of the relevant vehicle, an accident occurred by which injury was caused to any person. ${ }^{66}$ The basic offence of taking a vehicle is not one of strict liability, in that it requires knowledge of the absence of authority. However, the aggravated offence is constructive in nature and does not require explicit proof of a legally recognised species of mens rea as to an aspect (the resulting harm) of the offence, ${ }^{67}$ despite being a serious crime carrying a maximum sentence of two years' imprisonment, or 14 years if it causes death. ${ }^{68}$ Again there was no fault in the manner of D's driving of the stolen vehicle in Taylor, ${ }^{69}$ and the wording of the statute is more neutral in using the language of 'owing to the driving' rather than 'causes ... by driving', yet the Supreme Court held that there must be something properly to be criticised in the manner of D's driving. Throughout both judgments there are references to this being the normal common law approach to causation, ${ }^{70}$ or a common-sense meaning of causation, ${ }^{71}$ but, as we will discuss, the court elides causal responsibility with moral responsibility or blame. This section addresses two preliminary issues: the rationale for strict liability in tort and crime and the relationship between causal, moral, and legal responsibility. Following this discussion, we question how causation should be established for such liability under the two branches of law, ultimately arguing that adoption of a 'harm within the wrong' test in strict liability result crimes would be preferable to altering the meaning of causation more generally in order to bridge the gap between causal and moral responsibility.

65 Inserted by s 1 Aggravated Vehicle Taking Act 1992.

$66 \mathrm{R} v$ Taylor [2016] UKSC 5, [2016] 1 WLR 500.

67 Duff's definition of formal strict liability: R A Duff, Answering for Crime (Oxford University Press 2007) 233.

68 In R v Sherwood \& Button (1995) 16 Cr App R (S) 513 it was found that the different sentences provided under s 12A(4) Theft Act mean different offences are created, including one of 'causing death'.

69 Although D was drink-driving, the court focused narrowly on the manner of his driving and found that there was no fault.

$70 \quad \mathrm{R} v$ Hughes [2013] UKSC 56 at [16], [20], [27]; $\mathrm{R} v$ Taylor (n 54) [18].

$71 \mathrm{R} v$ Taylor (n 54) [23], [25]. 


\subsection{DiVERGENCE IN JUSTIFICATIONS OF STRICT LIABILITY}

The offences in both Hughes and Taylor were crimes of strict liability. Despite the conventional view that criminal liability is constructed through the commission of an actus reus committed with mens rea, there are an increasing number of regulatory offences that depart from this paradigmatic construction in relation to one, or other, or both requirements. In recent years, regulatory offences have come to dominate the criminal law, ${ }^{72}$ and these are often created as crimes of strict liability. Driving is one form of activity that is regulated through the criminal law in this way. Many driving offences are conduct crimes regulating the act of driving where no harm need result, meaning that causation is not an issue that need be addressed, and no knowledge of the wrong committed need be proved. This can be contrasted with offences of pollution where, again, knowledge of the wrong is not needed, but it must be proved that D's act or omission caused the pollution and is thus a result rather than conduct crime. These strict liability result crimes are difficult to fit into a rational exposition of the law, and the causal issues they raise are often addressed under an additional subheading by textbook writers in addition to the categories of breaks in the causal chain discussed in the previous section. ${ }^{73}$ The purported advantages of crimes of strict liability are certainty, efficiency and effectiveness. ${ }^{74}$ In Taylor the court observed that strict liability in criminal law is generally 'founded on collective convenience rather than moral imperatives' and 'although fault in the actual commission of the offence may be unnecessary, there are nonetheless positive steps that the prospect of criminal liability may cause people to take in order to prevent the offence from occurring. ${ }^{75}$

In comparison, strict liability is not widespread in tort law, ${ }^{76}$ and 'the strictness of the liability varies considerably along a spectrum from near absolute liability to little more than a reversed burden of proof' ${ }^{77}$ The rationale for strict liability is less clear-cut in tort, but Peel and Goudkamp suggest 'it is perhaps possible to discern behind some of them a very hazy idea of unusual or increased risk'. ${ }^{78}$

The regulatory criminal offence of driving without insurance is concerned not with the risk of physical damage but with the financial harm of road-users being unable to obtain compensation for damage or injury resulting from road traffic 'accidents'. ${ }^{79}$

72 Chalmers and Leverick found that 98 per cent of the 1395 offences created in 1997-1998 and 89 per cent of the 1760 offences created in 2010-2011 were regulatory in nature, applying to those acting in some form of special capacity: J Chalmers and F Leverick, 'Tracking the Creation of Criminal Offences' [2013] Criminal Law Review 543, 558.

73 'Two special cases of intervention: pollution and driving' is a sub-heading used in A P Simester, J R Spencer, F Stark, G R Sullivan and G J Virgo, Simester and Sullivan's Criminal Law: Theory and Doctrine (7th edn, Hart 2019) 108. 'Empress Car' is a subheading used in D Ormerod and K Laird, Smith and Hogan's Criminal Law (14th edn, Oxford University Press 2015) 99.

74 N Padfield, 'Clean Water and Muddy Causation: Is Causation a Question of Law or Fact, or just a Way of Allocating Blame?’ [1995] Criminal Law Review 683, 693. For a more nuanced defence of strict liability, see A P Simester, 'Is Strict Liability Always Wrong?' in A P Simester (ed), Appraising Strict Liability (Oxford University Press 2005).

$75 \mathrm{R} v$ Taylor (n 54) [26].

76 In the sense of 'outcome-based' strict liability, which Cane distinguishes from strict liability in the sense of simple interference with an interest of the claimant, and relationship-based strict liability in the form of vicarious liability: P Cane, 'Retribution, Proportionality, and Moral Luck in Tort Law' in P Cane and J Stapleton (eds), The Law of Obligations: Essays in Celebration of John Fleming (Clarendon Press 1998) 150.

77 W E Peel and J Goudkamp, Winfield and Jolowicz on Tort (19th edn, Sweet \& Maxwell 2014) 28.

78 Ibid.

79 A point made by Lords Hughes and Toulson at para [9] in Hughes (n 15). 
Stevens argues that regulatory offences are 'not dependent upon there being either an interpersonal wrong or want of moral virtue' so it is 'unsurprising that the offences can be committed blamelessly'. ${ }^{80}$ The s $3 \mathrm{ZB}$ offence is premised on a regulatory offence which is not justified by the risk of physical harm but the risk of such harm going uncompensated, yet it is ultimately a result crime so should depend upon an interpersonal wrong or want of moral virtue. While convenience and efficiency may be sufficient to justify regulatory offences 'especially where the offences involved are common and individually involve no serious harm or even any harm at all', 81 this rationale cannot extend to a homicide offence which by definition involves serious harm.

\subsection{DISTINGUISHING TYPES OF RESPONSIBILITY: CAUSAL, MORAL, AND LEGAL}

What does it mean to say that an individual is responsible for another's death? The debate here turns on the boundaries between causal responsibility, moral responsibility and legal liability, ${ }^{82}$ and the discussion of causation in Hughes does not adequately distinguish these concepts. Admittedly, the distinction between causal and moral responsibility is muddied in the law by the fact that the causation inquiry comprises both factual causation and legal causation, so legal causation introduces issues of moral responsibility into the realm of 'causation'. 83

Hart famously set out a range of forms of responsibility, distinguishing role responsibility, causal responsibility, legal and moral liability responsibility, and capacity responsibility. Notably, causal responsibility 'need not carry even an implication that [a person] was deserving of censure or praise; it may be purely a statement concerned with the contribution made by one human being to an outcome of importance, and be entirely neutral as to its moral or other merits'. ${ }^{84}$ Beever similarly distinguishes between causal responsibility and moral responsibility, using the following example:

Imagine that I am crossing a bridge on my way home from work. Though I have no reason to suspect it, the bridge has a structural weakness. The outcome of this weakness is that my being on the bridge causes it to collapse. Though I survive, the collapse causes the deaths of 10 people. ${ }^{85}$

He goes on to explain that he can accept causal responsibility for the deaths, but that does not mean he is personally morally responsible for them. ${ }^{86} \mathrm{He}$ suggests that there is no reason to think that it is inappropriate for the person crossing the bridge to think that this is 'something that happened to bim rather than something for which he was personally responsible'. ${ }^{87}$ This echoes Ashworth's concern about the role of outcome luck in the constructive crime of unlawful act manslaughter, that 'the fault and the result are simply

80 R Stevens, 'Private Rights and Public Wrongs' in M Dyson (ed), Unravelling Tort and Crime (n 2) 143.

81 Simester et al (n 73) 211.

82 For a discussion of these boundaries in the context of criminal responsibility and liability, see Duff (n 67).

83 See J Stapleton, 'Unpacking Causation' in P Cane and J Gardner (eds) Relating to Responsibility: Essays in Honour of Tony Honoré on bis 80th birthday (Oxford University Press 2001); J Stapleton, 'Choosing What We Mean by “Causation" in the Law' (2008) 73 Missouri Law Review 433, 446.

84 H L A Hart, Punishment and Responsibility: Essays in the Philosophy of Law (2nd edn, Oxford University Press 2008) 215. See also Simester (n 2) 416 and 422-433; A Beever, 'Corrective Justice and Personal Responsibility in Tort Law' (2008) 28 Oxford Journal of Legal Studies 475, 489.

85 Beever (n 84) 489.

86 Ibid 490 .

87 Ibid, original emphasis. 
too far apart for a manslaughter label to communicate anything other than the misfortune which befell both the victim and [D]'. ${ }^{88}$

In criminal law, in relation to the $\mathrm{s} 3 \mathrm{ZB}$ offence, we can say that causal responsibility rests on $\mathrm{D}$ in that D's driving of the car was a sine qua non connection with V's death, and a sine qua non connection is a causal connection. The subsequent narrowing that takes place to identify the responsible cause involves a value judgement dependent on context and the purpose of the inquiry. Fault is not a requirement for causation, but fault is often a requirement for moral responsibility and legal liability. Fault is not part of the character of causation, it is part of the character of the conduct to which the law will apply a test of causation.

Negligence lawyers and criminal lawyers may well disagree over this proposition, and one explanation is the different place occupied by causation in establishing liability. As previously discussed, in negligence the causation question is tightly framed by the damage and breach requirements, so the question is specifically whether D's breach of duty caused the damage suffered by the claimant, and it is simpler to separate the factual and moral issues. In criminal liability the causation inquiry is an element of establishing the actus reus so forms part of a more open-ended inquiry into what $\mathrm{D}$ did, where factual and moral issues are more tightly interwoven. However, in criminal law it is the requirement of mens rea which normally determines the presence of moral responsibility for serious result crimes. It is when mens rea is dispensed with that the problem of moral luck means that difficult questions are posed in relation to causation, since causation is required to do some of the work normally reserved for mens rea in establishing moral culpability for outcomes that were beyond D's control. ${ }^{89}$

\subsection{CAUSATION IN STRICT LIABILITY IN TORT AND CRIME}

Assuming that it is accepted that a sine qua non connection is a causal connection, it is still necessary to consider how to frame the counterfactual question that establishes factual causation in strict liability and in negligence. This is more straightforward in negligence since it is focused on D's breach of duty, so the formulation of the breach shapes the counterfactual question. The actual world is compared with a hypothetical world where D did not breach her duty. It is accepted that this hypothetical is a world where D conforms to the relevant standard of care; she cannot escape liability by arguing that she would have breached her duty in some other way and thereby still have caused the harm. ${ }^{90}$ Stapleton suggests that ' $[\mathrm{t}]$ he defendant's behaviour is altered just enough to bring it into conformity with his duty as mandated by the Law'. ${ }^{91}$ So, for example, where a defendant driver was speeding, the relevant hypothetical world is one where she was driving at a reasonable speed at the time of the accident. Hamer explains, "[i]t would be too much of a departure from the actual world to construct a possible world where the defendant was not driving at all'. ${ }^{92}$ More precisely, Wright says that we remove the tortious aspect of D's conduct

88 Ashworth (n 62) 120.

89 See text to $\mathrm{n} 87$ above.

90 Bolitho v City of Hackney Health Authority [1998] AC 232 (HL). Here, the doctor negligently failed to attend the patient who later suffered respiratory failure. She argued that, even if she had attended, she would not have intubated and that was the treatment that would have prevented respiratory failure. The House of Lords said the breach of duty test has to be applied to her hypothetical decision not to intubate; if that would also have been negligent then she is still a factual cause.

91 Stapleton, 'Choosing What We Mean by "Causation” in the Law' (n 83) 451, original emphasis.

92 D Hamer, “Factual Causation” and "Scope of Liability”: What's the Difference?' (2014) 77 Modern Law Review 155,164. 
since this 'ensur[es] that the reasons for making a person subject to liability govern and limit the extent of her liability'.93

If there were a duty of care in negligence to have public liability insurance when driving, the absence of insurance is the tortious aspect that would change in the hypothetical world. Having insurance would not change the outcome; if D was driving with reasonable care then the harm would still have occurred even if she had been insured. As noted by Merkin and Steele, 'absence of insurance does not itself cause death'. ${ }^{94}$ Thus, in The Empire Jamaica, ${ }^{95}$ there was no causal link between the fact that an officer (the defendant) navigating a ship did not have the certificate required by law and the collision that occurred while he was navigating. Honoré explains that ' $[\mathrm{g}]$ iven that the basis of liability was fault, it was rightly held that the lack of certificate was irrelevant, since the officer would have navigated no better had he possessed one'. ${ }^{96}$

In relation to The Empire Jamaica, Honoré goes on to argue, however:

$[\mathrm{H}] \mathrm{ad}$ there been strict liability for navigating the ship without a certificate, so that if the ship was navigated by a pilot without a certificate the navigation was at the defendants' risk, the navigation would have been held to have caused the collision. Since strict liability is liability not for wrongful conduct, but for engaging in risk-creating activity, there would have been no need in this case to show that the lack of certificate was causally relevant. In such a strict liability case, it would have been enough that, had the ship not been navigated by X (who did not in fact possess a certificate), no collision would have occurred. ${ }^{97}$

Effectively, he suggests that where liability is strict rather than fault-based, then the appropriate hypothetical is a world where the ship is not sailed at all, so for s $3 \mathrm{ZB}$ the relevant question is whether the fact of D's car being driven at all was a cause of V's death. In contrast to negligence law where the tortious aspect of D's conduct is substituted with reasonable conduct, Honoré explains that:

Substitution of lawful conduct is not possible and is not required in cases of strict liability, since the defendant's conduct, though it creates a risk, is not unlawful unless it causes harm. In such a case the hypothetical inquiry thus must be whether the plaintiff would have suffered the injury had the defendant not engaged in the activity . . . that entails strict liability. ${ }^{98}$

While the defendant in Hughes was engaged in a risky activity, viz driving, the particular risk being addressed by the $\mathrm{s} 3 \mathrm{ZB}$ offence was the financial risk of victims being uncompensated when injured by uninsured drivers. It is less than clear that the relevant hypothetical is a world in which the uninsured defendant does not drive at all, and in the following section we suggest that a 'harm within the wrong' test would allow courts to openly engage with consideration of what the relevant hypothetical is in any particular strict liability result crime.

93 R Wright, 'The Grounds and Extent of Legal Responsibility' (2003) 40 San Diego Law Review 1425, 1495. See also R Wright, 'Causation in Tort Law' (1985) 73 California Law Review 1735, 1805-06.

94 R Merkin and J Steele, 'Policing Tort and Crime with the MIB: Remedies, Penalties and the Duty to Insure' in M Dyson (ed), Unravelling Tort and Crime (n 2) 36.

95 NV Koninklijke Rotterdamsche Lloyd v Western Steamship Co Ltd (The Empire Jamaica) [1955] 3 WLR 385.

96 T Honoré, 'Necessary and Sufficient Conditions in Tort Law' in T Honoré, Responsibility and Fault (Oxford University Press 1999) 101. Broadbent similarly argues that a hypothetical world where the ship is not sailed at all would involve a 'gratuitous departure from the facts': A Broadbent, 'Fact and Law in the Causal Inquiry' (2009) 15 Legal Theory 173, 190.

97 Ibid.

98 Ibid 105-106. 


\subsection{FUTURE DIRECTIONS: A 'HARM WITHIN THE WRONG' TEST}

Ultimately, we agree with Simester that any discomfort in finding that Hughes caused death should be directed towards the legislator, ${ }^{99}$ which should not have created a strict liability homicide offence lacking in mens rea. But, given that these offences exist and appropriately require something more than causal responsibility, it is essential to address the question of what that 'something more' is, and where it can be injected. In addition to the existing tests of legal causation, it might be argued that criminal law would benefit, as Stuckenberg suggests, from a kind of remoteness principle akin to the 'harm within the risk' approach which originated in tort law (again with Lord Hoffmann) ${ }^{100}$ and asks whether the actual harm is of the kind which the violated rule was designed to prevent. ${ }^{101}$ While Turton has criticised the risk principle in negligence, ${ }^{102}$ the more relevant limitation of it in this context is that, as we have seen, strict liability in the criminal offences under consideration is not risk-based. A more appropriate test, we will suggest, would be a 'harm within the wrong' test. Focusing on the wrong further recognises the distinctive purpose for which the criminal law is acting, the purpose of expressing censure, and concretises Lord Hoffmann's assertion that one cannot determine issues of causation without first knowing the purpose and scope of the relevant rule.

Articulating the harm within the risk test, Lord Hoffmann gave the example of a mountain climber about to undertake a difficult climb who seeks medical advice about the fitness of his knee, and whose doctor negligently fails to diagnose a knee injury, meaning that the climber goes on to undertake a climb that they would not have undertaken had they known of the injury. Whilst climbing he suffers an injury that is a foreseeable consequence of mountaineering but unrelated to the fitness of his knee, such as being swept up in an avalanche. Although the doctor's negligence is a but-for cause of the climber's presence on the mountain and therefore of the subsequent injury, the scope of the doctor's duty of care does not extend to all mountaineering injuries, only those related to the fitness of the knee. ${ }^{103}$ The Model Penal Code (MPC) of the USA seeks to apply a 'harm within the risk' test to criminal liability. ${ }^{104}$ In relation to paradigmatic crime, the mens rea requirement (acting 'purposely or knowingly') will in most cases provide the basis of the causal relationship between the conduct and result. However, in relation to crimes of negligence and absolute (strict) liability, conditions are applied to the finding of causation:

\section{Model Penal Code $\$ 2.03$}

(3) When recklessly or negligently causing a particular result is an element of an offense, the element is not established if the actual result is not within the risk of which the actor is aware or, in the case of negligence, of which he should be aware unless:

(a) the actual result differs from the probable result only in the respect that a different person or different property is injured or affected or that the probable injury or harm would have been more serious or more extensive than that caused; or

99 Simester (n 2) 441.

100 South Australia Asset Management Corp v York Montague Ltd (SAAMCo) [1997] AC 191 (HL).

101 C-F Stuckenberg, 'Causation' in M D Dubber and T Hornle, The Oxford Handbook of Criminal Law (Oxford University Press 2014) 484-485.

102 G Turton, 'Informed Consent to Medical Treatment Post-Montgomery: Causation and Coincidence' (2019) 27 Medical Law Review 108, 122-130.

103 SAAMCo (n 100) 214.

104 See also Kyd (n 56). 
(b) the actual result involves the same kind of injury or harm as the probable result and is not too remote or accidental in its occurrence to have a [just] bearing on the actor's liability or on the gravity of his offense.

(4) When causing a particular result is a material element of an offense for which absolute liability is imposed by law, the element is not established unless the actual result is a probable consequence of the actor's conduct.

We can see here that, for offences requiring some form of mens rea, the test for causation is bound together with the state of mind of the defendant, according with psychologists' findings that ordinary people's judgement of causal selection may be affected by an independent judgment of blame. ${ }^{105}$ The problem is that such judgements will be made in the same way in relation to offences of strict liability, which cannot be catered for by the law, in that the very point of the law is that the defendant need not be aware of any risk. As a result, the test for 'absolute' offences is fudged in the MPC, with a rather woolly requirement that the result be a 'probable consequence' of the actor's conduct. This appears rather unsatisfactory to adopt without amendment if we are to introduce something similar here.

We would, therefore, seek to adapt the rule and, rather than frame the requirement in terms of risk, we would, instead, employ the concept of the wrong that the offence seeks to address. The regulatory offence of driving without insurance is not a moral wrong in itself and, as such, amounts to malum probibitum rather than malum in se, ${ }^{106}$ which exist to regulate driving on a public road and to prevent financial harm. Duff gives the examples of speeding and gun laws in noting that large parts of the criminal law take the form of coercive regulation, punishing conduct unconnected to wrongs to any persons. ${ }^{107}$ In order to create a constructive crime based on one of these underlying regulatory crimes of strict liability, then, there must exist a wrong in addition to the commission of such a regulatory offence. By injecting a requirement of minimal fault, we move from conduct that is unconnected to wrongs to any persons (driving whilst uninsured) to conduct that wrongs others, by increasing the risk of harm on the roads. ${ }^{108}$ In our view it is preferable that a court articulate these reasons, rather than obscuring them within causation, and adding a 'harm within the wrong' inquiry to strict liability offences facilitates this. We reach the same conclusion as the Supreme Court, but by using a principle that could have universal application throughout the criminal law.

The benefit of this 'harm within the wrong' approach that requires the identification of the purpose and scope of the rule prior to addressing causation is that it leaves the meaning of causation otherwise unaltered. If the Supreme Court's insistence that causation necessarily involves fault were to establish a general principle, it would change the outcome in a number of the earlier pollution cases. Adopting a 'harm within the

105 A Summers, 'Common-Sense Causation in Law' (2019) 39 Oxford Journal of Legal Studies 50-73.

106 See R A Duff, 'Rule-Violations and Wrongdoings' in S Shute and A P Simester, Criminal Law Theory: Doctrines of the General Part (Oxford University Press 2002) 55.

107 R A Duff 'Wrongs and Responsibility for Wrongs' in M Dyson (ed), Unravelling Tort and Crime (n 2) 98. Elsewhere Duff distinguishes between harmful wrongs and wrongful harms, noting that speeding is an implicit endangerment offence and carrying a firearm is an indirect endangerment offence, which suggests that these offences are neither harmful wrongs nor wrongful harms without some further wrongful action on the part of the agent: R A Duff, 'Criminalizing Endangerment' in R A Duff and S Green, Defining Crimes: Essays on the Special Part of the Criminal Law (Oxford University Press 2005).

108 It might be argued that, if the wrong lies in the creation of a second-order harm, or risk, that we should retain the label of 'harm within the risk', as used in tort. Our reasoning, though, is that the purpose of the criminal law, as distinct from tort, is to censure wrongdoing, and it is therefore essential to focus on the wrong that is being censured. 
wrong' test would facilitate confining the scope of Hughes to the s $3 \mathrm{ZB}$ offence and its ilk, ${ }^{109}$ forcing the courts to deal with the issue on a case-by-case basis, rather than providing a general principle of causation. Under 'harm within the wrong', the environmental cases would then remain unchanged, as is clear if we revisit Alphacell $v$ Woodward. ${ }^{110}$ The defendant in that case was found guilty of the offence under s 2(1)(a) Rivers (Prevention of Pollution) Act 1951 establishing that D commits an offence if he causes or knowingly permits to enter a stream any poisonous, noxious or polluting matter'. Although it was not established that there was any negligence on D's part, the pump in their water tank had become blocked by branches and the overflowing pollutant drained into a stream. They were still held to have 'caused' the pollutant to enter the stream since:

... the whole complex operation which might lead to this result was an operation deliberately conducted by the appellants and I fail to see how a defect in one stage of it, even if we can assume that this happened without their negligence, can enable them to say they did not cause the pollution. ${ }^{111}$

Lord Salmon explicitly drew the distinction between causal and legal responsibility, stating 'giving the word "cause" its ordinary and natural meaning, anyone may cause something to happen intentionally or negligently or inadvertently without negligence and without intention'. ${ }^{112}$ If we were to adopt the Supreme Court's definition of causation in Hughes, then we would require some element of fault in a pollution case such as Alphacell, whereas the 'harm within the wrong' approach allows us to identify that this is a risk-based strict liability offence such that the conduct to which we apply the test of causation is the act of engaging in activity with pollutants at all.

The key to the controversy surrounding s $3 Z \mathrm{~B}$ is the same as that identified by Padfield in her illuminating article in which she compares the approach taken to causation in the pollution case of National Rivers Authority v Yorkshire Water Services Ltd ${ }^{113}$ to the approach taken in cases of homicide. The problem, she suggested, is that 'we are reluctant to convict of homicide someone whom we do not blame'. ${ }^{114}$ Padfield wrote the article long before a homicide offence constructed on a regulatory driving offence had been created, as it now has been under the s $3 \mathrm{ZB}$ offence. What the pollution offences have in common with s $3 \mathrm{ZB}$, however, is that they are result crimes, despite also being crimes of strict liability. In relation to traditional offences requiring mens rea, the policy questions which dictate determination of fair imputation can be dealt with as part of the mens rea of the offence. As noted by Hart and Honoré, if a court 'is satisfied that it has before it on a charge of murder a criminal who wilfully inflicted grave injury, without which death would not have occurred', the pertinent question is 'whether it [is] socially advantageous to give legal effect to the relation between the defendant's acts and the death'. But what of offences which dispense with the need for mens rea for the purposes of efficiency? In environmental cases, such as Empress, Alphacell and Yorkshire Water Services Ltd, it is arguable that efficiency outweighs the absence of blame; it is socially advantageous to give effect to the relation between the defendant's acts (of e.g. discharging sewage into a river) and the result by holding that $\mathrm{D}$ caused the harm, given that the harm is within the wrong

109 Such as the aggravated TWOC (taking without consent) offence under s 12A Theft Act, as applied in R $v$ Taylor [2016] UKSC 5.

110 Alphacell Ltd v Woodward [1972] AC 824 (HL).

111 Ibid 834 (Lord Wilberforce).

112 Ibid 847 (Lord Salmon).

113 [1995] 1 All ER 225.

114 Padfield (n 74) 691. 
which the strict liability offence was designed to prevent (pollution). The individual or company convicted is censured for failing to ensure that a river is not polluted by the activities from which it profits.

Other strict liability regulatory offences do not raise issues of causation because they tend to be conduct crimes not requiring any particular harm to have been caused, such as the offences under the Health and Safety at Work Act 1974 which punish the secondorder harm of creating a risk of death or injury. Where that risk materialises and death is caused, the offence of corporate manslaughter is a result crime, where the 'harm within the wrong' requirement might be put to the test, with the prosecution having to prove that a gross breach of a duty of care caused V's death. In determining whether there was a gross breach of duty, the jury will have regard to any failure to comply with health and safety legislation. ${ }^{115}$ It is in this way that the 'harm within the wrong' test might be applied to corporate manslaughter: the wrong in failing to discharge the duty under s 2 Health and Safety at Work Act 1974, for example, is the creation of a risk to the health, safety and welfare at work of an employer's employees. Where that risk materialises in death, it is clear that the harm is located within the wrong that legislation was seeking to prevent and, provided the other elements of the corporate manslaughter offence are established (including that the breach was gross), liability for causing death should ensue.

\section{Concluding remarks}

The fact that a case on the requirements under s $3 Z \mathrm{~B}$ came to the attention of the Supreme Court so swiftly is to be welcomed, given the confusion amongst lawyers tasked with its application. ${ }^{116}$ Some prosecutors had previously suggested that the use of the word 'causing' under s $3 \mathrm{ZB}$ was problematic and incongruent with the purpose of the law, suggesting that it would have been better to have used the terminology 'owing to the presence of a vehicle on the road'117 (the terminology used under s 12A Theft Act) if the government really did think it appropriate to introduce a strict liability vehicular homicide offence. Yet, as the case of Taylor shows, with the Supreme Court now having interpreted $\mathrm{s} 12 \mathrm{~A}$ Theft Act in light of Hughes, it was not the specific choice of words in the statutory provision that was in issue; rather that the courts are objecting to strict liability homicide offences at all. This is made clear by Lord Sumption in Taylor, stating that the 'fundamental reason why the appeal should succeed' is that to do otherwise would be to accept the Crown's invitation to treat s $2 \mathrm{~A}$ as imposing strict liability for the aggravating factors. ${ }^{118}$

This paper has identified the complexity of the factors that shape the approach to causation in criminal law and negligence, showing that causation rules depend not only on the aims and justifications of the particular branch of law, but also the all or nothing nature of criminal liability compared to the allocation of responsibility that is possible within negligence and, crucially, on the place causation occupies in relation to the other elements of liability. Strict liability, whether in tort law or criminal law, raises distinct issues and is imposed for different reasons, and the introduction of a harm within the wrong' test for strict liability result crimes may help ensure that legal causation can be fully addressed in a way that reflects the functions of strict liability while confining liability within appropriate bounds. In an ideal world the legislature would respect the

115 Corporate Manslaughter and Corporate Homicide Act 2007, s 8.

116 See S Kyd Cunningham, 'Has Law Reform Policy been Driven in the Right Direction? How the New Causing Death by Driving Offences are Operating in Practice’ (2013) Criminal Law Review 711, 720-721.

117 Ibid.

$118 \mathrm{R} v$ Taylor (n 54) [23]. 
principle of correspondence to prevent creation of inappropriate strict liability homicide offences in the first place. However, where they do come into existence, the courts are right to develop a principle that avoids injustice prevailing. The Supreme Court's approach in Hughes and Taylor has the potential to develop into a 'harm within the wrong' test to ensure that requirements of causation can give effect to the role of the criminal law in censuring the blameworthy. 